\title{
PERAN PEREMPUAN SEBAGAI GARDA TERDEPAN DALAM KELUARGA DALAM MENINGKATKAN MOTIVASI BELAJAR ANAK DITENGAH PANDEMI COVID 19
}

\author{
Aisyatin Kamila \\ Pascasarjana UIN Sunan Kalijaga, Yogyakarta \\ E-mail: mielaairandah@gmail.com.085222063020
}

\begin{abstract}
The role of the mother is very important in the learning process of children while at home. The learning system that is carried out onlinebecause of the plaguecovid 19.Then the role of the mother needs to be maximized for the sake of the effectiveness of children's learning while at home. Especially in increasing motivation to learn in children.Because motivation in supporting it by learning is encouraging, encouraging all the power in encouraging children who are interesting, guaranteeing success and giving direction to learning activities, so that goals can be achieved. In learning activities, motivation is certainly very necessary, because someone who has no motivation in learning, will not be possible to do learning activities.
\end{abstract}

Keywords: The Role of the mother, Motivation

\begin{abstract}
Abstrak: Peran ibu merupakan hal sangat penting dalam proses belajar anak selama di rumah. Mengigat sistem pembelajaran yang dilakukan ini adalah secara online karena wabah covid 19, Maka peran ibu perlu di maksimalkan demi efekivias belajar anak selama di rumah. Terlebih dalam meningktakan motivasi belajar pada anak. Karena Motivasi dalam kaitannya dengan belajar adalah dorongan, keseluruhan daya penggerak di dalam diri anak yang menimbulkan, menjamin kelangsungan dan memberikan arah kegiatan belajar, sehingga diharapkan tujuan yang ada dapat tercapai. Dalam kegiatan belajar, motivasi tentu sangat diperlukan, sebab seseorang yang tidak mempunyai motivasi dalam belajar, tidak akan mungkin melakukan aktifitas belajar.
\end{abstract}

Kata Kunci: Peran Ibu, Motivasi 


\section{PENDAHULUAN}

Keluarga merupakan arena utama dan pertama untuk melakukan interaksi sosial dan mengenal perilaku-perilaku yang dilakukan oleh orang lain. Juga keluarga sebagai tonggak awal dalam pengenalan budaya-budaya masyarakat dalam mana anggota keluarga belajar tentang pribadi dan sifat orang lain di luar dirinya. Karena itu keluarga merupakan wadah yang memiliki arti penting dalam pembentukan karakter, hubungan kekerabatan, sosial dan kreativitas para anggotanya. (Ulfiyah, 2016)

Keluarga merupakan sarana pengasuhan bagi anak-anak untuk belajar hal-hal yang menyangkut masalah norma agama, nilai dan adat istiadat yang berlaku dalam masyarakat. Pengasuhan dapat didefinisikan sebagai pola perilaku yang diterapkan orangtua terhadap anakanaknya, melalui interaksi langsung atau tidak langsung, baik yang sifatnya memberi dukungan maupun yang bersifat menghambat anak, dalam segala aktifitas eksplorasi dan komitmen demi mencapai status identitas dirinya.

Di dalam interaksi orangtua dengan anak tercakup ekspresi atau pernyataan orangtua tentang sikap, nilai, dan minat orangtua yang pada akhirnya interaksi orangtua dengan anaknya inilah yang disebut sebagai gaya pengasuhan orangtua.

Berbicara mengenai pengasuhan terhadap anak, tak luput dari peran perempuan selaku istri dan juga ibu. peran perempuan menjadi sangat kompleks ketika sudah berkeluarga. Dikatakan bahwa tugas perempuan adalah melahirkan anak, memasak dan berdandan. Oleh karena itu perempuan dianggap sebagai anggota keluarga yang hanya mengurus urusan belakang, tidak boleh tampil di depan. Seberapa banyak uang yang didapat, tidak akan pernah dianggap pencari nafkah. Pembahasan mengenai perempuan seolah tidak ada habisnya, padakenyataannya isu gender memang banyak mengambil peran di berbagai sektor kehidupan seperti bidang ekonomi, politik, social-budaya hingga agama. Perempuan dalam kehidupan sosial selalu diasumsikan sebagai the second sex yang sangat menentukan mode representasi sosial tentang status dan peran perempuan.

Berbicara mengenai perempuan, tidak hanya lepas dari peran dan tugas perempuan dalam dunia pendidikan, maka kaum perempuan selain sebagai objek juga sebagai subjek pendidikan khususnya dalam ranah keluarga.Dalam kehidupan keluarga, suami istri umumnya memegang peranan dalam pembinaan kesejahteraan bersama, secara fisik, materi maupun spiritual juga dalam meningkatan kedudukan keluarga dalam masyarakat.

Peran perempuan, dalam keluaga adalah sebagai istri, ibu atau bahkan anak. Semua peran tersebut menuntut adanya tugas sesuai dengan perannya masing-masing. Perempuan sebagai ibu adalah dimana perempuan sebagai orang pertama yang berinteraksi langsung dengan anak, yang mendidik dan mengajarkan tentang kehidupan. Untuk itu perempuan harus mampu memahami perannya dalam pendidikan anak sebagai bagian dari keluarga atau sebagai ibu.

Beberapa topik bahasan tentang perempuan telah banyak ditulis dan dibukukan serta ada dalam sejarah. Baik dari kacamata agama, hukum, negara, sosial bahkan lingkup psikologi.

Penelitian dari Khaerany (2016) merekomendasikan perlunya setiap anggota keluarga agar meningkatkan 
kesadaran diri untuk menjalankan setiap fungsi dan perannya sebagai anggota keluarga agar tercipta suasana yang harmonis dalam keluarga dan diharapkan kepada pemerintahan untuk senantiasa memberdayakan kaum perempuan diberbagai sektor kehidupan tanpa mengabaikan kepentingan keluarga perempuan tersebut.

Hal ini menunjukkan betapa pentingnya peran perempuan sebagai garda terdepan dalam setiap lini kehidupan. Terutama dalam keluarga. sehingga, memungkinkan seorang perempuan sebagai jantung pendidikan bagi anak-anaknya dalam membangun karakter anakmenjadi generasi unggul. Eksistensi perempuan sebagai pendidik dan pembentuk karakter awal anak, menjadikan kedudukan kaum perempuan lebih istimewa dibandingkan dengan kaum laki-laki. (Lestari, 2016).

Beberapa bulan terakhir ini, Indonesia bahkan dunia menerapkan sistem belajar di rumah hal ini dikarenakan adanya wabah virus yang disebut corova virus / covid 19 (Coronavirus disease 2019). Corova virus adalah penyakit menular yang disebabkan SARS-CoV-2. Salah satu jenis korona virus dan mengakibatkan pandemi koronavirus 2019-2020. virus yang mulanya berasal dari koa Wuhan ini telah banyak melumpuhkan berbagai sektor kehidupan. Termasuk sektor di bidang pendidikan. Hingga menyebabkan pemerinah indonesia memutuskan kebijakan terhadappembelajaran di sekolah dilakkan secara daring.

Dalam masa pandemi ini, peran ibu merupakan hal sangat penting dalam proses belajar anak selama di rumah. Mengigat sistem pembelajaran yang dilakukan ini adalah secara online. Maka peran ibu perlu di maksimalkan demi efekivias belajar anak selama di rumah. Terlebih dalam meningktakan motivasi belajar pada anak. Karena Motivasi dalam kaitannya dengan belajar adalah dorongan, keseluruhan daya penggerak di dalam diri siswa yang menimbulkan, menjamin kelangsungan dan memberikan arah kegiatan belajar, sehingga diharapkan tujuan yang ada dapat tercapai. Dalam kegiatan belajar, motivasi tentu sangat diperlukan, sebab seseorang yang tidak mempunyai motivasi dalam belajar, tidak akan mungkin melakukan aktifitas belajar.

\section{Perempuan dan Keluarga}

\section{Definisi Peran}

Menurut Horoepoetri (Mustadjar, 2013), Beberapa dimensi peran sebagai berikut:

a. Peran sebagai suatu kebijakan, yaitu peran dalam suatu kebijaksanaan yang tepat dan baik untuk dilaksanakan.

b. Peran sebagai strategi yaitu peran untuk mendapatkan dukungan masyarakat (public support) dalam akses terhadap pengambilan keputusan dan kepedulian pada tingkatan pengambilan keputusan yang didokumentasikan dengan baik, sehingga keputusan tersebut akan memiliki kredibilitas.

c. Peran sebagai alat komunikasi, yakni peran yang digunakan sebagai instrument atau alat untuk mendapatkan masukan berupa informasi dalam proses pengambilan keputusan.

d. Peran sebagai terapi yakni dilakukan sebagai upaya mengobati masalahmasalah psikologis masyarakat seperti perasaan ketidakberdayaan (sense of powerlessness) tidak percaya diri dan perasaan bahwa diri 
mereka bukan komponen penting dalam masyarakat.

\section{Pengertian Keluarga}

Keluarga merupakan arena utama dan pertama untuk melakukan interaksi sosial dan mengenal perilaku-perilaku yang dilakukan oleh orang lain. Juga keluarga sebagai tonggak awal dalam pengenalan budaya-budaya masyarakat dalam mana anggota keluarga belajar tentang pribadi dan sifat orang lain di luar dirinya. Karena itu keluarga merupakan wadah yang memiliki arti penting dalam pembentukan karakter, hubungan kekerabatan, sosial dan kreativitas para anggotanya.

\section{Peran Keluarga}

Keluarga merupakan lingkungan pertama dan utama bagi anak untuk membentuk kepribadian dan mencapai tugas-tugas perkembangannya. Oleh karena itu, keluarga menjadi faktor yang terpenting bagi pembentukan sikap dan prilaku anak baik dalam segi kepribadian, sosial maupun emosional anak. Keluarga memiliki peran yang sangat penting dalam upaya mengembangkan kepribadian anak. Perawatan orangtua yang penuh kasih sayang dan pendidikan tentang nilainilai kehidupan, baik agama maupun sosial budaya yang diberikan merupakan faktor yang sangat mendukung untuk mempersiapkan anak menjadi pribadi dan anggota masyarakat yang baik.

\section{Peran perempuan dalam keluarga}

Seorang perempuan mempunyai peran dalam kehidupan berumah tangga untuk mengatur segala urusan rumah tangga, terutama memberikan kasih sayang kepada anak-anaknya. Soetrisno (1997) mangatakan, bahwa perempuan dituntut untuk memiliki suatu sikap mandiri, disamping suatu kebebasan untuk mengembangkan dirinya sesuai dengan bakat yang dimilikinya, disatu sisi perempuan dituntut untuk berperan semua aktor, tetapi disisi lain muncul pula tuntunan lain agar perempuan tidak melupakn kodrat mereka sebagai perempuan.

Secara garis besar, peran dan tugas perempuan dalam keluarga yaitu: 1. Peran perempuan sebagai ibu dalam keluarga

Keluarga merupakan arena utama dan pertama untuk melakukan interaksi sosial dan mengenal perilaku-perilaku yang dilakukan oleh orang lain. Juga keluarga sebagai tonggak awal dalam pengenalan budaya-budaya masyarakat dalam mana anggota keluarga belajar tentang pribadi dan sifat orang lain di luar dirinya. Karena itu keluarga merupakan wadah yang memiliki arti penting dalam pembentukan karakter, hubungan kekerabatan, sosial dan kreativitas para anggotanya.Keluarga merupakan unit sosial pertama dan utama sebagai pondasi primer bagi perkembangan anak.

Berbicara mengenai pendidikan anak, maka yang paling besar pengaruhnya adalah ibu. Ditangan ibu keberhasilan pendidikan anak-anaknya walaupun tentunya keikutsertaan bapak tidak dapat diabaikan begitu saja. Ibu memainkan peran yang penting di dalam mendidik anakanaknya, terutama pada masa balita.

Peranan ibu di dalam mendidik anaknya dibedakan menurut Musjtari (nd) menjadi tiga tugas penting, yaitu:

a. Ibu yang selalu menyediakan kebutuhan anak-anak, yaitu fungsi ibu sebagai sumber pemenuhan kebutuhan ini sangat besar artinya bagi anak, terutama pada saat anak di dalam ketergantungan total terhadap 
ibunya, yang akan tetap berlangsung sampai periode anak sekolah, bahkan sampai menjelang dewasa. Ibu perlu menyediakan waktu bukan saja untuk selalu bersama tetapi untuk selalu berinteraksi maupun

berkomunikasi secara terbuka dengan anaknya.

b. Ibu sebagai teladan atau model peniruan anak. Dalam hal ini hendaknya orang tua harus dapat menjadi contoh yang positif bagi anak-anaknya. Anak akan mengambil nilai-nilai, sikap maupun perilaku orang tua, tidak hanya apa yang secara sadar diberikan pada anaknya misal melalui nasehat-nasehat, tetapi juga dari perilaku orang tua yang tidak disadari. Jadi, untuk melakukan peran sebagai model, maka ibu sendiri harus sudah memiliki nila-nilai itu sebagai milik pribadinya yang tercermin dalam sikap dan perilakunya. Hal ini penting, artinya bagi proses belajar anak-anak dalam usaha untuk menyerap apa yang ditanamkan.

c. Ibu sebagai pemberi stimulasi bagi perkembangan anak. Perkembangan mental anak akan sangat ditentukan oleh seberapa rangsang yang diberikan ibu terhadap anaknya. Rangsangan dapat berupa cerita-cerita, macammacam alat permainan yang edukatif maupun kesempatan untuk rekreasi yang dapat memperkaya pengalamannya.

2. Peran perempuan sebagai istri

Sebagai seorang istri perempuan berperan dalam mengabdikan diri kepada suaminya. Selain itu seorang istri juga selalu mensupport suaminya baik dalam pekerjaan atau kegiatan lainnya. Dibalik laki-laki (suami) yang hebat terdapat perempuan (istri) yang hebat pula. Lestari (2002) menjelaskan peran istri sebagai mitra suami, yang membantu dan mendampingi suami dalam kehidupan keluarga. Begitu besar peran perempuan sebagai Istri sehingga banyak laki-laki yang sukses karena dibelakangnya ada istri yang sangat luar biasa.

\section{Motivasi Belajar}

Djamarah (2002) menjelaskan jika motivasi secara psikologi dipandang sebagai gejala psikologis yang berupa dorongan yang timbul pada diri seseorang baik secara sadar atupun tidak sadar untuk melakukan tindakan dengan tujuan tertentu. Motivasi ialah penggerak ataupun dorongan dalam perbuatan, individu yang memiliki motivasi yang tinggi akan tergerak untuk melakukan hal yang ingin diraihnya. Mc Donald (dalam Sardiman, 2007) mengemukakan bahwa motivasi ialah perubahan energi dalam individu yang ditandai dengan munculnya "feeling" dan didahului dengan tanggapan terhadap adanya tujuan. Ada tiga elemen yang terkandung dalam pernyataan Mc Donald tersebut yaitu: 1) Motivasi mengawali terjadinya perubahan energi pada setiap individu.

Walaupun motivasi itu muncul dari dalam diri manusia, penampakannya akan menyangkut kegiatan fisik manusia; 2) Motivasi ditandai dengan munculnya rasa/ feeling, afeksi seseorang. Dalam hal ini motivasi relevan dengan persoalanpersoalan kejiwaan, afeksi dan emosi yang dapat menentukan tingkah laku manusia; dan 3) Motivasi akan dirangsang karena adanya tujuan. Jadi, motivasi dalam hal ini sebenarnya merupakan respons dari suatu aksi yaitu 
tujuan. Tujuan ini menyangkut soal kebutuhan.

Sadirman (2007) menyatakan bahwa motivasi dibagi menjadi motivasi intrinstik dan ekstrinsik:

\section{Motivasi Intrinstik}

Motivasi intrinsik yaitu motif-motif yang tidak perlu dirangsang dari luar, karena dalam diri setiap individu sudah ada dorongang untuk melakukan seseuatu. Jika dilihat dari segi tujuan kegiatan belajar maka yang dimaksud motivasi intrinsik ini adalah ingin mencapai tujuan yang terkandung di dalam perbuatan belajar itu sendiri. Jadi motivasi muncul dari kesadaran diri sendiri dengan tujuan secara esensial, bukan sekadar simbol dan seremonial.

\section{Motivasi Ekstrinsik}

Motivasi ekstrinsik adalah motifmotif yang aktif dan akan berfungsi ketika adanya rangsang dari luar. Misalnya seseorang belajar pada malam hari ini karena esok hari akan ujian dengan harapan mendapat nilai yang baik dan pujian. Jadi bukan karena belajar ingin mengetahui sesuatu, tetapi ingin mendapat nilai bagus atau pujian. Oleh karena itu, motivasi ekstrinsik dapat juga dikatakan sebagi bentuk motivasi yang di dalamnya aktivitas belajar dimulai dan diteruskan berdasarkan dorongan dari luar yang tidak mutlak berkaitan dengan aktivitas belajar.

Motivasi dapat diketahui dari beberapa indikator. Hamzah (2009) membagi menjadi sembilan indikator motivasi yaitu: 1) Tekun dalam menghadapi tugas, 2) Ulet menghadapi kesulitan, 3) Tidak memerlukan dorongan luar untuk berprestasi, 4) Ingin mendalami bahan atau bidang pengetahuan yang diberikan, 5) Selalu berusaha berprestasi sebaik mungkin, 6) Menunjukkan minat terhadap macam- macam masalah "dewasa" misalkan ialah pembangunan, korupsi, keadilan dan sebagainya, 7) Senang dan rajin belajar, penuh semangat, cepat bosan, dan tugas-tugas rutin dapat mempertahankan pendapatpendapatnya, 8) mengejar tujuan jangka panjang, 9) Senang mencari dan memecahkan soal dan permasalahan. (Hamzah, 2009)

Terdapat tiga fungsi motivasi menurut Hamalik (2003) yaitu ialah :

1. Mendorong timbulnya kelakuan atau sesuatu perbuatan. Tanpa motivasi maka tidak akan timbul suatu perbuatan seperti belajar.

2. Motivasi berfungsi sebagai pengarah artinya menggerakkan perbuatan kearah pencapaian tujuan yang diinginkannya.

3. Motivasi berfungsi sebagai penggerak. Motivasi berfungsi sebagai mesin, besar kecilnya motivasi akan menentukan cepat atau lambannya pekerjaan

Sardiman (2007) mengemukakan bentuk dan cara untuk menumbuhkan motivasi diantaranya ialah :

1. Memberikan point/angka

Angka dalam hal ini adalah nilai. Banyak siswa yang beranggapan, belajar untuk mendapatkan angka atau nilai yang baik. Oleh karena itu, langkah yang perlu dilakukan seorang guru adalah bagaimana memberikan angka yang terkait dengan values yang terkandung dalam setiap pengetahuan siswa sehingga tidak hanya nilai kognitif saja tetapi juga keterampilan afeksinya.

\section{Hadiah}

Hadiah dapat juga dikatakan sebagai motivasi, tetapi tidaklah selalu demikian. Karena hadiah untuk suatu pekerjaan, mungkin tidak akan menarik bagi seseorang yang tidak senang dan 
tidak berbakat untuk suatu pekerjaan tersebut.

3. Saingan/kompetisi

Saingan atau kompetisi dapat digunakan sebagai alat motivasi untuk mendorong belajar siswa. Persaingan antar individual maupun kelompok dapat meningkatkan prestasi belajar siswa.

\section{Ego-involvent}

Menumbuhkan kesadaran kepada siswa agar merasakan pentingnya tugas dan menerimanya sebagai tantangan sehingga bekerja keras dengan mempertaruhkan harga diri adalah sebagai salah satu bentuk motivasi yang cukup penting. Penyelesaian tugas dengan baik adalah simbol kebanggaan dan harga diri bagi siswa.

5. Memberi ulangan.

Memberi ulangan merupakan salah satu sarana motivasi. Tetapi dalam memberikan ulangan jangan terlalu sering, karena siswa akan merasa bosan dan bersifat rutinitas.

\section{Mengetahui Hasil}

Dengan mengetahui hasil pekerjaan, apalagi kalau terjadi kemajuan, akan mendorong siswa untuk lebih giat belajar. Semakin mengetahui bahwa grafik hasil belajar meningkat, maka ada motivasi pada diri siswa untuk terus belajar, dengan suatu harapan hasilnya terus meningkat.

7. Pujian

Pujian ini adalah bentuk reinforcement yang positif dan sekaligus merupakan motivasi yang baik. Dengan pujian yang tepat akan menciptakan suasana yang menyenangkan dan mempertinggi gairah belajar serta sekaligus akan membangkitkan harga diri.

8. Hukuman

Hukuman sebagai reinforcement yang negatif tetapi kalau diberikan secara tepat dan bijak bisa menjadi alat motivasi.

9. Tujuan yang diakui

Rumusan tujuan yang diakui dan diterima baik oleh siswa, merupakan alat motivasi yang sangat tepat. Sebab dengan memahami tujuan yang harus dicapai, karena dirasa sangat berguna dan menguntungkan, maka akan timbul gairah untuk terus belajar.

10. Minat

Minat ialah alat motivasi yang pokok. Karena proses belajar akan berjalan lancar apabila disertai dengan minat.

\section{METODE PENELITIAN}

Penelitian ini menggunakan jenis penelitian library research (Studi Pustaka) menurut Embun metode library research adalah penelitian yang dilakukan hanya didasarkan atas karya tertulis, termasuk hasil penelitian baik yang telah maupun yang belum dipublikasikan. (Melfianora, 2017)

Sehingga dalam penelitian ini, peneliti melakukan analisis dari berbagai macam sumber yang berkaitan dengan judul yang peniliti angkat dan menarik suatu analisis yang akurat dan kritis untuk melahirkan sintesa baru, rasional dan logis serta menjadi sebuah kesimpulan yang dapata di uji dilapangan. Metode ini mengambil refensi dari beberapa buku, jurnal dan artikel sehingga mempertajam hasil analisis dari peneliti

\section{PEMBAHASAN}

\section{Peran Ibu Dalam Meningkatkan Motivasi Belajar Anak Ditengah Pandemi Covid 19}

Motivasi belajar penting adanya, jauh lebih penting dari pada semua bakat dan kemampuan anak dalam 
bidang-bidang tertentu. Anak yang memiliki motivasi belajar mereka akan mampu mengatasi rintangan yang ada dan mendorong diri sendiri untuk mengoptimalkan potensi terbaik yang mereka punyai, sehingga berpeluang mengubah kegagalan menjadi sebuah prestasi.

Dalam hal ini, orang tua terutama ibu berkewaiban memberikan pendamingan dan edukasi pada anak dalam meningkatkan motivasi belajar saat masa pandemi yang menghabiskan waktu di rumah saja.

Hal yang dapat dilakukan orang tua dalam meningkatkan motivasi belajar ditengah pandemi covid 829 adalah sebagai berik:

1. Memberikan edukasi

Fungsi edukasi adalah fungsi keluarga yang berkaitan dengan pendidikan anak khususnya dan pendidikan serta pembinaan anggota keluarga pada umumnya. Fungsi edukasi ini tidak sekedar menyangkut pelaksanaannya,

melainkan menyangkut pola penentuan dan pengukuhan landasan yang mendasari pendidikan itu, pengarahan dan perumusan tujuan pendidikan, perencanaan dan pengelolaan, penyediaan dana dan sarana, pengayaan wawasan dan lain sebagainya yang ada kaitannya dengan pendidikan.

\section{Bimbingan belajar}

Bimbingan belajar diperlukan untuk meningkatkan motivasi belajar pada anak. Karena Belajar merupakan suatu proses dari seorang individu yang berupaya mencapai tujuan belajar yang merupakan bentuk perubahan perilaku yang relatif menetap. Oleh karena itu untuk memperoleh hasil belajar yang baik dan maksimal diperlukan persiapan anak dalam belajar yang baik pula. Persiapan anak dalam belajar merupakan kebutuhan pokok yang harus dipenuhi oleh anak dalam mencapai hasil belajar. Kesiapan belajar jangan hanya diterjemahkan siap dalam arti fisik, tetapi juga diartikan dalam arti psikis dan materiil. Kesiapan fisik misal kondisi badan yang sehat. Kesiapan materiil misalnya adanya buku bacaan, materi pelajaran, catatan, modul. Kesiapan psikis misalnya ada hasrat untuk belajar, konsentrasi, dan adanya motivasi. Untuk mencapai hasil belajar yang diinginkan diperlukan motivasi belajar, supaya ada kiat-kiat dan tindakan untuk mencapai hasil yang diinginkan oleh siswa tersebut. Selama pembelajaran di rumah, ibu memberikan bimbingan belajar pada anak agar tetap termotivasi untuk belajar dan memanfaakan efekifias waku.

Selain itu, Djamaraoh (2002) menjelaskan ibu dapat mengontrol waktudan cara belajar anak selama di rumah, memantauperkembangan kemampuan akademik anak, memantau kepribadian sikap, moral, dan tingkah laku anak, memantau efekifikas jam belajar pada anak.

\section{SIMPULAN}

Peran perempuan, dalam keluaga adalah sebagai istri, ibu atau bahkan anak. Semua peran tersebut menuntut adanya tugas sesuai dengan perannya masing-masing. Perempuan sebagai ibu adalah dimana perempuan sebagai orang pertama yang berinteraksi langsung dengan anak, yang mendidik dan mengajarkan tentang kehidupan. Untuk itu perempuan harus mampu memahami perannya dalam pendidikan anak sebagai bagian dari keluarga atau sebagai ibu.

Motivasi memiliki peran penting dalam proses belajar, jika motivasi tepat diberikan kepada anak maka ia akan 
mencapai keberhasilan yang maksimal. Seorang anak yang memiliki motivasi belajar tinggi, pada umumnya mampu mencapai keberhasilan dalam proses maupun hasil belajar. Di masa andemi seeri sekarang ini, eran orang a erama ib adalah hal yang aling ama diberikan keada anak dalam meningkakan moivasi belaar. Hal yang daa diemh oleh ib dalam meningkakan moivasi belaae anak adalah dengan memberikan edukasi, bimbingan belajar, mengontrol waktu dan cara belajar anak selama di rumah, memantau perkembangan kemampuan akademik anak, memantau kepribadian sikap, moral, dan tingkah laku anak, memantau efekifikas jam belajar pada anak.

\section{DAFTAR PUSTAKA}

Ahmad,

Suhendra.

2012. REKONSTRUKSI PERAN DAN HAK PEREMPUAN DALAM ORGANISASI MASYARAKAT ISLAM. Musãwa 11, no. 1 (January 2012).

Djamarah, \& Syaiful Bahri. 2002. Strategi Belajar Mengajar. Jakarta: Rineka Cipta

Ulfiyah 2016

PSIKOLOGI KELUARGA, Pemahaman Hakikat Keluarga Dan Penanganan Problemaika Keluarga. Bogor: Ghalia Indonesia

Khaerany, Nuralfi. Peran Ganda Perempuan Pada Keluarga Petani Desa Pallantikang Kabupaten Gowa (n.d.).

Lestari, Dian. 2016. Eksistensi Perempuan Dalam Keluarga (Kajian Peran Perempuan Sebagai Jantung Pendidikan Anak). MUWAZAH $8, \quad$ no. 2 (Desember 2016).

Musjtari, Dewi Nurul. Peran Dan Tugas Perempuan Dalam Keluarga, n.d.
Nurwandi, Andri, Nawir Yuslem, \& Sukiati. 2018. Kedudukan Dan Peran Perempuan Sebagai Kepala Keluarga Menurut Hukum Islam (Studi Terhadap Kelompok Pemberdayaan Perempuan Kepala KeluargaPEKKA Di Kabupaten Asahan)." AT-TAFAHUM Journal of Islamic Law 2, no. 1 (June 2018).

Oemar Hamalik. 2004. Proses Belajar Mengajar. Jakarta: Bumi aksara,

Rachman, Budi Munawar. 1996. Rekonstruksi Figh Perempuan Dalam Peradaban Masyaraakat Modern. Cet. 1. Yogyakarta: Ababil.

Sardiman, A. M. 2007. Interaksi Dan Motivasi Belajar Mengajar. Jakarta: Grafindo Persada.

Sari, Diana. 2007. Peran Orang Tua Dalam Meningkatkan Motivasi Belajar Pada Anak (November 25, 2017).

Soetrisno, Loekman. 1997. Kemiskinan, Perempuan, Dan Pemberdayaan. Yogyakarta: Kanisius.

Syaiful Bahri Djamarah. 2002. Psikologi Belajar. Jakarta: Rineka Cipta

Uni Hamzah. 2009. Teori Motivasi Dan Pengukurannya. Jakarta: Bumi aksara. 